\title{
Anti-MDA5 juvenile idiopathic inflammatory myopathy with second-degree heart block but no skin or lung involvement: a case report
}

\author{
Meghan E. Ryan ${ }^{1}$, Daniel Cortez ${ }^{2}$, Kelly R. Dietz ${ }^{3}$, Peter Karachunski ${ }^{4}$ and Bryce A. Binstadt ${ }^{1 *}$ (D)
}

\begin{abstract}
Background: Patients with idiopathic inflammatory myopathy and autoantibodies directed against melanoma differentiation-associated protein 5 (MDA5) characteristically have interstitial lung disease, severe cutaneous involvement, arthritis, and relatively mild myositis. Cardiac involvement in idiopathic inflammatory myopathy can occur and has been associated with anti-signal recognition particle and anti-polymyositis-scleroderma autoantibodies, but not with anti-MDA5 autoantibodies.

Case presentation: A 14-year-old male presented with weakness, second-degree heart block, arthritis, and hematologic cytopenias. Imaging and biopsies confirmed the diagnosis of juvenile idiopathic inflammatory myopathy, and he had high titer anti-MDA5 autoantibodies. There were no cutaneous or pulmonary abnormalities. While on prednisone and methotrexate, the patient's heart block improved from second- to first-degree and the cytopenias resolved. Persistent myositis prompted the addition of intravenous immunoglobulin. Seven months into the disease course, the arthritis and myositis are in remission and the patient is no longer taking corticosteroids.

Conclusions: We report a novel case of a patient with juvenile idiopathic myositis who lacked the typical cutaneous and pulmonary findings associated with anti-MDA5 positivity, but who had cardiac conduction defects. This report broadens the clinical spectrum of anti-MDA5-associated inflammatory myopathy.
\end{abstract}

Keywords: Case report, Juvenile idiopathic inflammatory myopathy, Heart block, Anti-melanoma differentiation-associated protein 5

\section{Background}

Patients with idiopathic inflammatory myopathy (IIM) and autoantibodies directed against melanoma differentiation-associated protein 5 (anti-MDA5) characteristically have interstitial lung disease (ILD), severe cutaneous involvement, arthritis, and relatively mild myositis. Arthritis

\footnotetext{
* Correspondence: binstadt@umn.edu

'Department of Pediatrics, Division of Rheumatology, Allergy \& Immunology, University of Minnesota, Minneapolis, USA

Full list of author information is available at the end of the article
}

is reported in $100 \%$ of IIM patients with anti-MDA5 antibodies. The other features vary in incidence between study populations but appear to occur more commonly in patients with anti-MDA5 compared to other myositis autoantibodies [1-5]. Cardiac involvement and the lack of either cutaneous or lung abnormalities in juvenile IIM (JIIM) patients with anti-MDA5 antibodies has not been documented previously. We describe a unique case of a patient with anti-MDA5-associated JIIM.

(c) The Author(s). 2021 Open Access This article is licensed under a Creative Commons Attribution 4.0 International License, which permits use, sharing, adaptation, distribution and reproduction in any medium or format, as long as you give appropriate credit to the original author(s) and the source, provide a link to the Creative Commons licence, and indicate if changes were made. The images or other third party material in this article are included in the article's Creative Commons licence, unless indicated otherwise in a credit line to the material. If material is not included in the article's Creative Commons licence and your intended use is not permitted by statutory regulation or exceeds the permitted use, you will need to obtain permission directly from the copyright holder. To view a copy of this licence, visit http://creativecommons.org/licenses/by/4.0/ The Creative Commons Public Domain Dedication waiver (http://creativecommons.org/publicdomain/zero/1.0/) applies to the data made available in this article, unless otherwise stated in a credit line to the data. 


\section{Case presentation}

A 14-year-old male with history of alopecia areata presented with a 2-month history of progressive fatigue, $5 \mathrm{~kg}$ weight loss, muscle weakness, and painful swollen joints. Physical examination revealed arthritis in the wrists and several finger joints, myalgias with initially normal strength, and a small patch of alopecia on his head. He had no rash, and his lungs were clear. He underwent an extensive evaluation for malignancy, infections, and systemic rheumatic diseases. Evaluation was notable for cytopenias (nadir leukocytes $2.7 \times 10^{9} / \mathrm{L}$, lymphocytes $0.9 \times 10^{9} / \mathrm{L}$, hemoglobin $10.5 \mathrm{~g} / \mathrm{dL}$, platelets $137 \times 10^{9} / \mathrm{L}$ ), but examination of the bone marrow was normal. Anti-platelet antibodies were not detected. Parvovirus titers demonstrated past exposure. He had intermittently elevated muscle enzymes (AST $83 \mathrm{U} / \mathrm{L}$ [reference range $0-50 \mathrm{U} / \mathrm{L}$ ], aldolase $10.9 \mathrm{U} / \mathrm{L}$ [reference range 3.3-9.7 U/L], CK $318 \mathrm{U} / \mathrm{L}$ [reference range 30-225 $\mathrm{U} / \mathrm{L}$ ], LDH $694 \mathrm{U} / \mathrm{L}$ [reference range 0-337 U/L]), and normal von Willebrand factor antigen at initial presentation.

Magnetic resonance imaging (MRI) of his pelvis and proximal thighs revealed both myositis and fasciitis (Fig. 1a). Examination of his hands showed no cutaneous disease (Fig. 1b). Computed tomography of the chest was normal (Fig. 1c). A muscle biopsy from his left quadricep muscle demonstrated findings consistent with inflammatory myopathy similar to dermatomyositis (Fig. 1d). The patchy distribution of myositis found on MRI and muscle histology correlated with his mild myositis on exam. A myositis autoantibody panel revealed high positive anti-MDA5 antibodies but no other specific antibodies. Intermittent, asymptomatic high-grade second-degree heart block was identified via electrocardiogram and telemetry (Fig. 1e). Cardiac laboratory evaluation was notable for transiently elevated $\mathrm{N}$-terminal pro btype natriuretic peptide $820 \mathrm{pg} / \mathrm{mL}$ [reference range $0-240 \mathrm{pg} / \mathrm{mL}$ ], but troponin I ES was normal. No additional cardiac testing was done.

He was diagnosed with JIIM and started on oral methotrexate (15 mg weekly) and oral prednisone (20 mg daily). After 2 weeks of treatment, he continued to have active myositis. Therefore, he was started on intravenous methylprednisolone (1 g weekly) in addition to increased oral methotrexate $(25 \mathrm{mg}$ weekly) and oral prednisone $(40 \mathrm{mg}$ daily). One month into therapy, he had mild improvement in his myalgias and improvement in his heart block from second- to first-degree. His cytopenias resolved and muscle enzymes improved but remained slightly elevated. His von Willibrand factor antigen was now mildly elevated. Pulmonary function testing was normal with DLCO of $72 \%$. Monthly intravenous immunoglobulin (IVIG) was added due to persistent weakness and myalgias. His myositis improved more significantly with the addition of IVIG, allowing tapering and eventual discontinuation of the corticosteroids. Five months into treatment, the patient continues to lack the cutaneous or pulmonary features characteristically associated with anti-MDA5 seropositivity. His arthritis has resolved, strength is normal, and muscle enzymes have normalized. His most recent pulmonary function tests were again normal with an improved DLCO of $83 \%$.

\section{Discussion and conclusions}

There are no prior reports of patients with antiMDA5 JIIM who lack both cutaneous and pulmonary features. In a recent case series that included 13 patients with anti-MDA5 JIIM, 9 patients had ILD at some point in their disease course. The onset of ILD occurred a median of 4 months after diagnosis with one patient developing ILD as late as 85 months after diagnosis [3]. Hence, it is possible that our patient could still develop pulmonary involvement.

This patient uniquely had second-degree heart block which has not been previously described in anti-MDA5 positive JIIM patients. In general, cardiac abnormalities are uncommon in patients with JIIM. A large, multicenter study reported cardiac abnormalities in only $2.9 \%$ of $>400$ juvenile dermatomyositis patients, including myocarditis, pericarditis, and conduction defects; however, this study contained no information regarding autoantibodies [6]. Myositis autoantibodies previously associated with cardiac abnormalities in JIIM patients include anti-signal recognition particle and anti-polymyositis-scleroderma $[5,7]$. To our knowledge, there is only one other case report of conduction abnormalities in antiMDA5 IIM: a 68-year-old female who had complete heart block [8]. We speculate that our patient had inflammatory changes within the myocardium that resulted in the observed conduction abnormalities. The resolution of his heart block after immunomodulatory treatments is consistent with this notion. Literature regarding the responsiveness of IIM-associated conduction defects to immunomodulatory therapy is mixed, with one report demonstrating improvement in some children, but not in adults [9].

In conclusion, cardiac conduction abnormalities can occur in anti-MDA5-associated JIIM. Furthermore, JIIM can arise in the absence of ILD or cutaneous abnormalities. Close monitoring for ILD is recommended for IIM patients with anti-MDA5 seropositivity. Evaluation for 

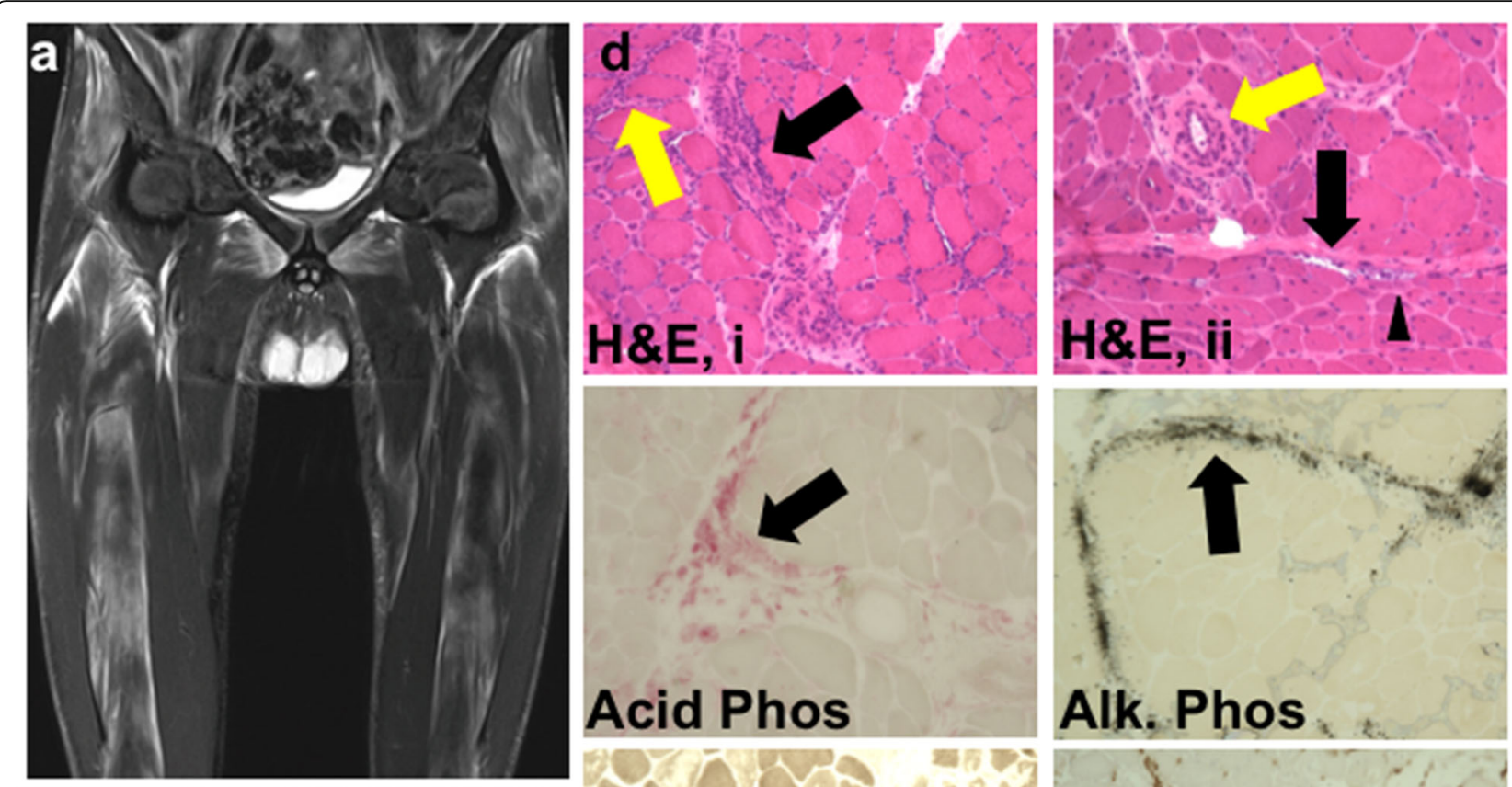

\section{Acid Phos}

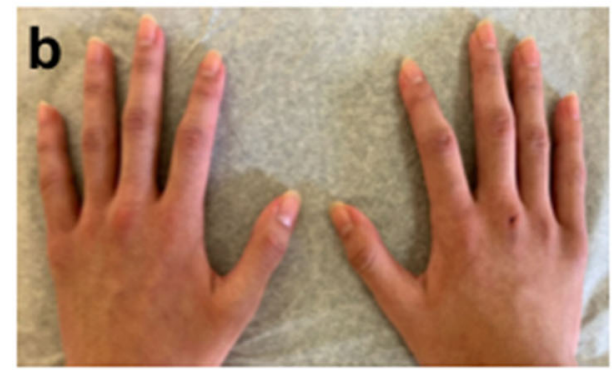

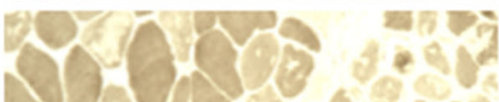

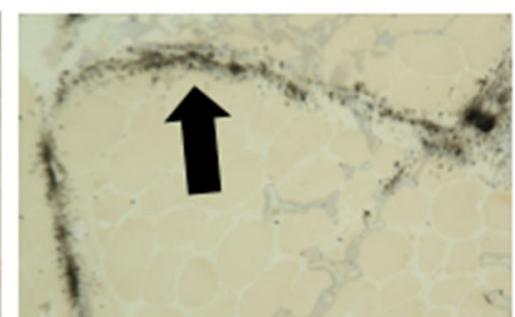

Alk, Phos
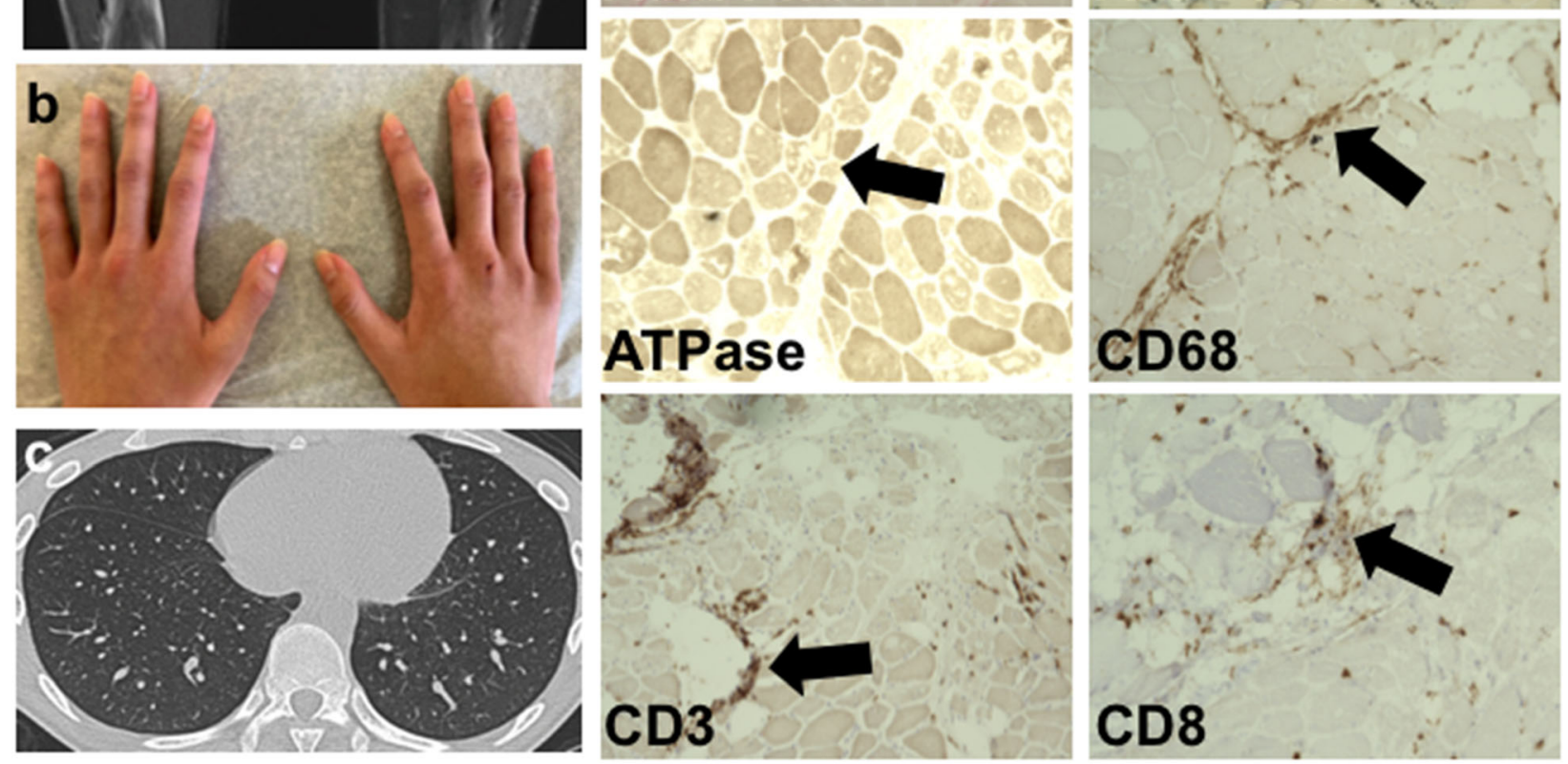

$300-0,9$

\section{ATPase}
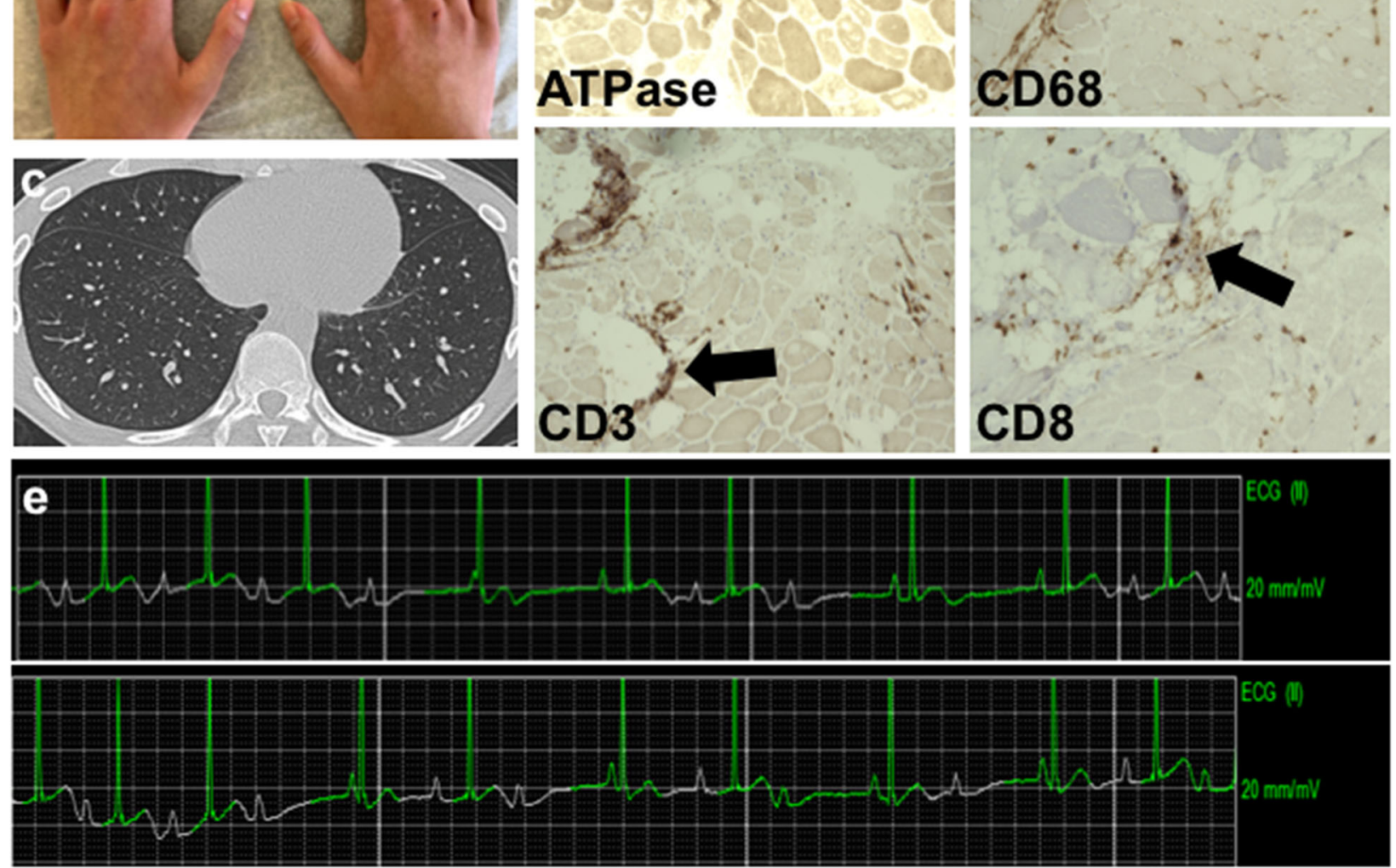

Fig. 1 (See legend on next page.) 
(See figure on previous page.)

Fig. 1 Representative images from an adolescent with anti-MDA5 JIIM. a Pelvis and thigh MRI without contrast coronal STIR view demonstrating patchy increased signal intensity. $\mathbf{b}$ Absence of rash on hands $\mathbf{c}$ Normal non-contrast chest computed tomography, axial view $\mathbf{d}$ Muscle biopsy stained with the indicated dyes or antibodies. H\&E, i: Perimysial (black arrow) and endomysial (yellow arrow) inflammatory infiltrates. H\&E, ii: Highlights marked fiber size variation with perifascicular atrophy with fibers showing purple discoloration and disrupted internal architecture (black arrow), perivascular inflammation (yellow arrow), many muscle fibers have central nuclei and vacuolar degeneration (arrowhead). Acid Phosphatase: Red staining predominantly in perimysium highlights inflammation involving histiocytes. Alkaline Phosphatase: Black staining highlights perimysial connective tissue reactivity. ATPase shows highlights of perifascicular atrophy and patchy loss of staining indicative of necrosis and degeneration (black arrow). AntiCD68 staining localized to areas of inflammation involving histiocytes, especially in perimysium (arrows). Anti-CD3 and CD8 staining localized to areas of T-cell lymphocytic infiltrates (arrows). e Telemetry: top: Bradycardia with Wenckebach; bottom: 2:1 atrioventricular block

cardiac conduction defects and other cardiac abnormalities is also recommended.

\section{Abbreviations}

AST: Aspartate aminotransferase; CK: Creatine kinase; DLCO: Diffusing capacity for carbon monoxide; IIM: Idiopathic inflammatory myopathy; ILD: Interstitial lung disease; IVIG: Intravenous immunoglobulin; JIIM: Juvenile idiopathic inflammatory myopathy; LDH: Lactate dehydrogenase; MRI: Magnetic resonance imaging; MDA5: Melanoma differentiationassociated protein 5

\section{Acknowledgements}

Not applicable.

\section{Authors' contributions}

MR wrote the manuscript and collected data and images from the other authors. DC analyzed, interpreted, and provided electrocardiogram findings. KD analyzed, interpreted, and provided the radiographic images. PK analyzed, interpreted, and provided the histologic images. BB mentored MR and edited the manuscript. All authors read and approved the final manuscript.

\section{Funding}

No specific funding was received from any bodies in the public, commercial or not-for-profit sectors to carry out the work described in this article.

\section{Availability of data and materials}

Not applicable.

\section{Ethics approval and consent to participate}

Not applicable.

\section{Consent for publication}

Written informed consent was obtained from the patient's legal guardian(s) for publication of this case report and any accompanying images. A copy of the written consent is available for review by the Editor-in-Chief of this journal.

\section{Competing interests}

Authors declare no conflicts of interest.

\section{Author details}

${ }^{1}$ Department of Pediatrics, Division of Rheumatology, Allergy \& Immunology, University of Minnesota, Minneapolis, USA. ${ }^{2}$ Department of Pediatrics, Division of Cardiology, University of Minnesota, Minneapolis, USA.

${ }^{3}$ Department of Radiology, University of Minnesota, Minneapolis, USA.

${ }^{4}$ Department of Neurology, University of Minnesota, Minneapolis, USA.

Received: 16 November 2020 Accepted: 31 January 2021

Published online: 02 April 2021

\section{References}

1. Hoshino K, Muro Y, Sugiura K, Tomita Y, Nakashima R, Mimori T. Anti-MDA5 and anti-TIF1-gamma antibodies have clinical significance for patients with dermatomyositis. Rheumatology (Oxford). 2010;49(9):1726-33.

2. Tansley SL, Betteridge ZE, Gunawardena H, Jacques TS, Owens CM, Pilkington C, et al. Anti-MDA5 autoantibodies in juvenile dermatomyositis identify a distinct clinical phenotype: a prospective cohort study. Arthritis Res Ther. 2014;16(4):R138.

3. Melki I, Devilliers H, Gitiaux C, Bondet V, Duffy D, Charuel J-L, et al. AntiMDA5 juvenile idiopathic inflammatory myopathy: a specific subgroup defined by differentially enhanced interferon-a signalling. Rheumatology (Oxford). 2020;59(8):1927-37.

4. Betteridge Z, McHugh N. Myositis-specific autoantibodies: an important tool to support diagnosis of myositis. J Intern Med. 2016;280(1):8-23.

5. Wu J-Q, Lu M-P, Reed AM. Juvenile dermatomyositis: advances in clinical presentation, myositis-specific antibodies and treatment. World J Pediatr. 2020;16(1):31-43.

6. Ravelli A, Trail L, Ferrari C, Ruperto N, Pistorio A, Pilkington C, et al. Longterm outcome and prognostic factors of juvenile dermatomyositis: a multinational, multicenter study of 490 patients. Arthritis Care Res (Hoboken). 2010;62(1):63-72.

7. Pachman LM, Khojah AM. Advances in juvenile dermatomyositis: myositis specific antibodies aid in understanding disease heterogeneity. J Pediatr. 2018;195:16-27.

8. Sakamoto N, Ishimoto H, Nakashima S, Yura H, Miyamura T, Okuno D, et al. Clinical features of anti-MDA5 antibody-positive rapidly progressive interstitial lung disease without signs of dermatomyositis. Intern Med. 2019; 58(6):837-41.

9. Stern R, Godbold JH, Chess Q, Kagen LJ. ECG abnormalities in polymyositis. Arch Intern Med. 1984;144(11):2185-9.

\section{Publisher's Note}

Springer Nature remains neutral with regard to jurisdictional claims in published maps and institutional affiliations.
Ready to submit your research? Choose BMC and benefit from:

- fast, convenient online submission

- thorough peer review by experienced researchers in your field

- rapid publication on acceptance

- support for research data, including large and complex data types

- gold Open Access which fosters wider collaboration and increased citations

- maximum visibility for your research: over $100 \mathrm{M}$ website views per year

At BMC, research is always in progress.

Learn more biomedcentral.com/submissions 